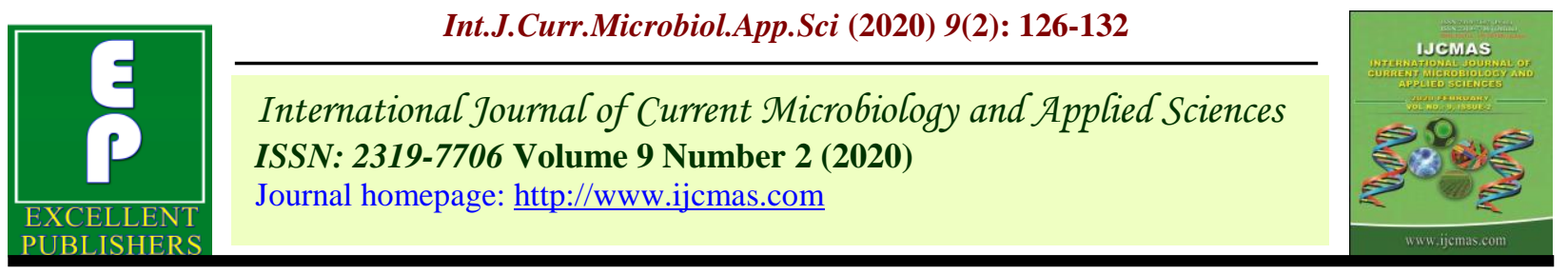

Original Research Article

https://doi.org/10.20546/ijcmas.2020.902.015

\title{
Performance of Different Varieties of Carrot (Daucus carota L.) with Respect Yield, Quality and Chemical Compositions under Varying Sowing Times
}

\author{
R. G. Ladumor ${ }^{1}$, B. M. Nandre ${ }^{2 *}$, M. K. Sharma ${ }^{2}$, V. R. Wankhade ${ }^{3}$ and P. C. Joshi ${ }^{3}$ \\ ${ }^{1}$ Department of Vegetable Science, College of Horticulture, S. D. Agricultural University, \\ Jagudan, India \\ ${ }^{2}$ Department of Horticulture, College of Agriculture, \\ S. D. Agricultural University, Tharad, India \\ ${ }^{3}$ Department of Horticulture, C.P. College of Agriculture, S. D. Agricultural University, \\ Sardarkrushinagar, India \\ *Corresponding author
}

\section{Keywords}

Carrot variety, Growth, Quality, Sowing date and yield

Article Info

Accepted: 05 January 2020 Available Online: 10 February 2020

\section{A B S T R A C T}

The present investigation was carried out at Horticulture farm, College of Horticulture, S. D. Agricultural University, Jagudan, Mehsana, Gujarat, to find out the performance of different varieties of carrot (Daucus carota L.) with respect yield, quality and chemical compositions under varying sowing times during rabi season 2017-18, comprising three dates of sowing $1^{\text {st }}$ October $\left(d_{1}\right), 15^{\text {th }}$ October $\left(\mathrm{d}_{2}\right)$ and $1^{\text {st }}$ November $\left(\mathrm{d}_{3}\right)$ and four varieties Patan Local $\left(\mathrm{v}_{1}\right)$, Pusa Vasuda $\left(\mathrm{v}_{2}\right)$, Pusa Rudhira $\left(\mathrm{v}_{3}\right)$ and Gujarat Dantiwada Carrot 1 (GDC 1) $\left(\mathrm{v}_{4}\right)$. The total twelve treatment combinations were tested in Split Plot Design with three replications. Observations recorded on growth, yield and quality parameters. Among the date of sowing, $15^{\text {th }}$ October $\left(\mathrm{d}_{2}\right)$ recorded significantly maximum weight of root $(72.10$ g), root yield per plot $(6.44 \mathrm{~kg})$, root yield per ha $(20.44 \mathrm{t})$, productivity per day $(247.70 \mathrm{~kg})$, root length $(22.31 \mathrm{~cm})$, collar diameter $(37.62 \mathrm{~mm})$, volume of root $(75.32 \mathrm{cc})$, total soluble solid $\left(8.00^{\circ} \mathrm{B}\right)$, reducing, non-reducing and total sugar (4.40, 3.50 and $7.90 \%$, respectively). All parameters showed a decreasing trend as sowing date was delayed. Variety Pusa Vasuda $\left(\mathrm{v}_{2}\right)$ recorded maximum weight of root $(70.24 \mathrm{~g})$, root yield per plot $(6.23 \mathrm{~kg})$, root yield per ha $(19.78 \mathrm{t})$, productivity per day $(241.48 \mathrm{~kg})$, root length $(23.04 \mathrm{~cm})$, collar diameter $(37.96$ $\mathrm{mm})$, volume of root $(71.12 \mathrm{cc})$, total soluble solid $\left(8.21^{\circ} \mathrm{B}\right)$, reducing, nonreducing and total sugar $(4.64,3.49$ and $8.13 \%$, respectively). 


\section{Introduction}

Amongst the root vegetables, carrot (Daucus carota L.) family Umbeliferae (Apiaceae) is a popular cool season root vegetable. It is a pronominal vegetable crop in European countries, USA, China, Japan and Korea. Carrot cultivars are broadly classified into two groups' viz., Asiatic or Oriental types and European or Temperate types. In India carrot cultivars grown in Punjab, U.P, Andhra Pradesh, Karnataka, Assam and Haryana are belongs to the Asiatic group.

The world-wide area and consumption, of carrot is increasing rapidly over the years due to good source of vitamin A along with the fair amount vitamin $\mathrm{B}$ and $\mathrm{C}$, rich in sugars, where sucrose is the most abundant endogenous sugar but the production per unit area is very poor. One of the major factors responsible for low yield of this crop is its economically proved cultivars and climatic limitations. Generally the ultimate aim of the investigation is to increase the yield per unit area because it is largely dependent on performance of the cultivar. Even a slight increase in yield will greatly be appreciated by the cultivar. Also higher temperature was reported to reduce top growth. Changes in the agro climatic conditions including day and night temperature associated with sowing date which affects carrot yield and quality. Growth and yield pattern of carrots are affected by varietal performance and change in climatic conditions so suitable cultivar and time of sowing are most important factors should be taken into consideration by the cultivators, which influence the vegetative growth, yield, quality and chemical compositions of carrot.

\section{Materials and Methods}

The present investigation was carried out at Horticulture farm, College of Horticulture, S. D. Agricultural University, Jagudan,
Mehsana, Gujarat, to evaluate performances of different varieties of carrot (Daucus carota L.) with respect yield, quality and chemical compositions under varying sowing times during rabi season 2017-18, comprising three dates of sowing $1^{\text {st }}$ October $\left(\mathrm{d}_{1}\right), 15^{\text {th }}$ October $\left(\mathrm{d}_{2}\right)$ and $1^{\text {st }}$ November $\left(\mathrm{d}_{3}\right)$ and four varieties Patan Local $\left(\mathrm{v}_{1}\right)$, Pusa Vasuda $\left(\mathrm{v}_{2}\right)$, Pusa Rudhira $\left(\mathrm{v}_{3}\right)$ and Gujarat Dantiwada Carrot 1 (GDC 1) $\left(\mathrm{v}_{4}\right)$. The total twelve treatment combinations were tested in Split Plot Design with three replications. The mean data recorded on weight of root, root yield per plot, root yield per hectare, productivity per day, root length, collar diameter, volume of root, total soluble solid, reducing, nonreducing and total sugar was subjected to statistical analysis following analysis of variance technique (Panse and Sukhatme, 1985).

\section{Results and Discussion}

\section{Yield parameters}

Inspection of data in Table 1 showed significantly maximum weight of root $(72.10$ $\mathrm{g})$, root yield per plot $(6.44 \mathrm{~kg})$, root yield per ha $(20.44 \mathrm{t})$, productivity per day $(247.70 \mathrm{~kg})$ was recorded by date of sowing $15^{\text {th }}$ October $\left(\mathrm{d}_{2}\right)$. All parameters showed a decreasing trend as sowing date was delayed.

Weight of root $(70.24 \mathrm{~g})$, root yield per plot $(6.23 \mathrm{~kg})$, root yield per ha $(19.78 \mathrm{t})$ and productivity per day $(241.48 \mathrm{~kg})$ was recorded on variety $\mathrm{v}_{2}$ (Pusa Vasuda).

A gradual decrease root weight was noted with delayed sowing time, which proved a negative correlation and short growing period with limited vegetative growth of late sown crop. Carrot is a photo and thermo sensitive crop. Growth of root was developed under a sustainable environmental condition. Later sowing could not provide their suitable 
environmental conditions to grow up properly. So earlier sowing was the best for higher fresh weight of root, Kabir et al., (2013). The higher root weight per plant were due to more number of leaves and leaf area for photosynthesis and efficient utilization of these photosynthates, might have enhanced the weight of root, Patel et al., (2015). The result corroborate with finding of Salah et al., (2005) and Patel et al., (2015) in sugar beet and Alam et al., (2010) in radish.

The variations in weight of root among different carrot varieties might be due to the varietal difference. The results of the present investigation are similar to that of Mapari et al., (2009) and Dongarawar et al., (2018) in radish.

The variation in root yield per plot and yield per hectare at varying sowing times may be due to more favourable environmental condition to development in earlier sowing and also vigorous vegetative growth resulted by more photosynthates and favourable weather conditions might have helped to increase yield. The increase in root yield with October planting might be attributed to the good weather conditions that promoted photosynthesis and improved growth of beet root, hence increase root yield, Patel et al., (2015). The increase in total root yield due to its positive correlation with root diameter and root weight this type of differences was also reported by Alam et al., (2010) in sugar beet and Ebrahimi et al., (2013) in radish. There is a corresponding reduction in the yield of roots with the delay in the sowing of carrots after November. This might be due to very low temperatures during later sowings, which turn energy from vegetative phase to reproductive phase, Latha et al., (2012) in carrot.

The root yield per plot and root yield per hectare is a result of translocation of more quantum of carbohydrates from the source to the sink. As the varieties which have shown superior performance in yield have significantly more number of vigorous leaves on it and more plant height, which could have synthesized more food material and supplied to the roots, that might have resulted in increasing the weight and diameter of roots and ultimately resulted in getting higher root yield in these varieties, these results are inconformity with finding of Dongarawar et al., (2018) in radish.

\section{Quality parameters and chemical compositions}

Root length $(22.31 \mathrm{~cm})$, collar diameter $(37.62 \mathrm{~mm})$, volume of root $(75.32 \mathrm{cc})$, total soluble solid $\left(8.00^{\circ} \mathrm{B}\right)$, and reducing, nonreducing and total sugar $(4.40,3.50$ and 7.90 $\%$, respectively) was recorded date of sowing, $15^{\text {th }}$ October $\left(\mathrm{d}_{2}\right)$. All parameters showed a decreasing trend as sowing date was delayed.

Root length (23.04 cm), collar diameter (37.96 mm), volume of root $(71.12 \mathrm{cc})$, total soluble solid $\left(8.21^{\circ} \mathrm{B}\right)$, and reducing, nonreducing and total sugar $(4.64,3.49$ and 8.13 $\%$, respectively) was recorded on variety $\mathrm{v}_{2}$ (Pusa Vasuda).

Root length might be due to gradual decrease in temperature during later part of season in November, which influenced early transition of the plants from vegetative to reproductive phase. Also, up take of more nutrients and rate of photosynthesis was higher than other plants so that vegetative growth was increased and the carrot roots were rich in carbohydrate, Kabir et al., (2013). Such results are obtained on account of favourable conditions available during the growing period and also early sowing possibly attributed to maximum photosynthesis with longer growth period than the later plantings which also faced severe winter months after planting causing cessation of growth, Latha et al., (2012) in carrot. Present results are in conformity with Latha et al., (2012) and Kabir et al., (2013) in 
carrot. The root length of a cultivar is the factor which is of main concern to the research. Medium long root is an important character regarding root quality and it is useful to classify the varieties for consumer acceptability which might be due to genetical diversity in different varieties and ecological condition, Dongarawar et al., (2018). The difference between the two beet root cultivars under study could be due to the difference in the genetic makeup and their response to the environmental conditions, Patel et al., (2015). Results of the present investigation are similar to that of Patel et al., (2015) in sugar beet and Dongarawar et al., (2018) in radish.

The rapid increase in collar diameter of root was because of more vigorous growth in earlier sowing, which supplies more photosynthates from leaves to roots, Patel et al., (2015). Similar results of more root diameter were reported by Alam et al., (2010) in radish and Patel et al., (2015) in sugar beet.

The collar diameter root was significantly influenced among the different varieties. This denotes that these differences due to varietal response might be due to genetic composition in the expression of growth potentials, Latha et al., (2012) in carrot. The similar variations in collar diameter of root among different radish varieties have reported Dongarawar et al., (2018).

Early sowing resulted in higher size of root because of congenial growing condition and leads to maximum volume of root these results are conformity with the finding of Mirecki, (2005) in brussels sprout.

Table.1 Different varieties of carrot with respect yield, quality and chemical compositions under varying sowing times

\begin{tabular}{|c|c|c|c|c|c|c|c|c|c|c|c|}
\hline Treatment & $\begin{array}{l}\text { Weight } \\
\text { of root } \\
\text { (g) }\end{array}$ & $\begin{array}{c}\text { Root } \\
\text { yield } \\
\text { per plot } \\
(\mathbf{k g})\end{array}$ & $\begin{array}{c}\text { Root } \\
\text { yield per } \\
\text { hectare }(t)\end{array}$ & $\begin{array}{l}\text { Productivit } \\
\text { y per day } \\
\text { (kg) }\end{array}$ & $\begin{array}{c}\text { Root } \\
\text { length } \\
(\mathrm{cm})\end{array}$ & $\begin{array}{c}\text { Collar } \\
\text { diameter } \\
\text { of root } \\
(\mathbf{m m})\end{array}$ & $\begin{array}{c}\text { Volum } \\
\text { e of } \\
\text { root } \\
\text { (cc) }\end{array}$ & $\begin{array}{l}\text { TSS } \\
\left({ }^{\circ} \mathbf{B}\right)\end{array}$ & $\begin{array}{c}\text { Reducin } \\
\text { g sugar } \\
(\%)\end{array}$ & $\begin{array}{c}\text { Non } \\
\text { reducing } \\
\text { sugar } \\
(\%)\end{array}$ & $\begin{array}{c}\text { Total } \\
\text { sugar } \\
(\%)\end{array}$ \\
\hline \multicolumn{12}{|c|}{ Dates of Sowing (d) } \\
\hline$d_{1}: 1^{\text {st }}$ October & 68.96 & 6.00 & 19.05 & 214.30 & 20.02 & 35.87 & 70.73 & 7.66 & 3.94 & 3.09 & 7.03 \\
\hline$d_{2}: 15^{\text {th }}$ October & 72.10 & 6.44 & 20.44 & 247.70 & 22.31 & 37.62 & 75.32 & 8.00 & 4.40 & 3.50 & 7.90 \\
\hline $\begin{array}{l}d_{3}: 1^{\text {st }} \\
\text { November }\end{array}$ & 60.72 & 5.03 & 15.98 & 180.31 & 18.60 & 31.40 & 55.69 & 7.19 & 4.23 & 3.22 & 7.45 \\
\hline S. Em. \pm & 1.72 & 0.23 & 0.72 & 9.35 & 0.67 & 0.88 & 1.49 & 0.10 & 0.04 & 0.04 & 0.07 \\
\hline C. D. at $5 \%$ & 6.74 & 0.90 & 2.84 & 36.69 & 2.62 & 3.45 & 5.85 & 0.38 & 0.16 & 0.16 & 0.27 \\
\hline C. V. \% & 8.85 & 13.59 & 13.57 & 15.12 & 11.39 & 8.71 & 7.67 & 4.34 & 3.27 & 4.32 & 3.15 \\
\hline \multicolumn{12}{|l|}{ Varieties (v) } \\
\hline$v_{1}$ : Patan Local & 68.43 & 6.14 & 19.50 & 226.70 & 19.56 & 35.02 & 68.36 & 7.29 & 3.90 & 3.06 & 6.96 \\
\hline $\mathrm{v}_{2}$ : Pusa Vasuda & 70.24 & 6.23 & 19.78 & 241.48 & 23.04 & 37.96 & 71.12 & 8.21 & 4.64 & 3.49 & 8.13 \\
\hline $\begin{array}{l}v_{3}: \text { Pusa } \\
\text { Rudhira }\end{array}$ & 62.05 & 5.24 & 16.62 & 181.19 & 19.13 & 32.66 & 63.81 & 7.70 & 4.21 & 3.38 & 7.59 \\
\hline $\mathrm{v}_{4}:$ GDC 1 & 68.34 & 5.69 & 18.07 & 207.04 & 19.50 & 34.20 & 65.71 & 7.27 & 4.01 & 3.14 & 7.15 \\
\hline S. Em. \pm & 1.41 & 0.25 & 0.78 & 10.23 & 0.73 & 0.72 & 1.72 & 0.10 & 0.04 & 0.04 & 0.07 \\
\hline C. D. at $5 \%$ & 4.20 & 0.73 & 2.33 & 30.41 & 2.15 & 2.13 & 5.10 & 0.28 & 0.13 & 0.13 & 0.21 \\
\hline
\end{tabular}


Table.2 Interaction effect of sowing date and different varieties

\begin{tabular}{|c|c|c|c|c|}
\hline \multicolumn{2}{|r|}{ Treatment combination } & Root yield & Root yield per & Productivity per \\
\hline$d_{1} \mathbf{v}_{1}$ & $1^{\text {st }}$ October, Patan Local & 5.82 & 18.49 & 211.58 \\
\hline $\mathbf{d}_{1} \mathbf{v}_{2}$ & $1^{\text {st }}$ October, Pusa Vasuda & 6.41 & 20.34 & 242.89 \\
\hline$d_{1} v_{3}$ & $1^{\text {st }}$ October, Pusa Rudhira & 6.00 & 19.06 & 203.23 \\
\hline$d_{1} \mathbf{v}_{4}$ & $1^{\text {st }}$ October, Gujarat Dantiwada Carrot 1 & 5.77 & 18.33 & 199.50 \\
\hline $\mathbf{d}_{2} \mathbf{v}_{1}$ & $15^{\text {th }}$ October, Patan Local & 7.04 & 22.36 & 271.21 \\
\hline $\mathbf{d}_{2} \mathbf{v}_{2}$ & $15^{\text {th }}$ October, Pusa Vasuda & 7.62 & 24.18 & 308.81 \\
\hline $\mathbf{d}_{2} \mathbf{v}_{3}$ & $15^{\text {th }}$ October, Pusa Rudhira & 5.41 & 17.18 & 197.62 \\
\hline $\mathbf{d}_{2} \mathbf{v}_{4}$ & $15^{\text {th }}$ October, Gujarat Dantiwada carrot 1 & 5.69 & 18.05 & 213.13 \\
\hline $\mathbf{d}_{3} \mathbf{v}_{\mathbf{1}}$ & $1^{\text {st }}$ November, Patan Local & 5.56 & 17.65 & 197.30 \\
\hline $\mathbf{d}_{3} \mathbf{v}_{2}$ & $1^{\text {st }}$ November, Pusa Vasuda & 4.67 & 14.82 & 172.73 \\
\hline$d_{3} \mathbf{v}_{3}$ & $1^{\text {st }}$ November, Pusa Rudhira & 4.29 & 13.63 & 142.71 \\
\hline $\mathbf{d}_{3} \mathbf{v}_{4}$ & $1^{\text {st }}$ November, Gujarat Dantiwada Carrot 1 & 5.61 & 17.82 & 208.49 \\
\hline \multicolumn{2}{|c|}{ S. Em. \pm} & 0.43 & 1.36 & 17.73 \\
\hline \multicolumn{2}{|c|}{ C. D. at $5 \%$} & 1.27 & 4.04 & 52.67 \\
\hline \multicolumn{2}{|c|}{ C. V. $\%$} & 12.72 & 12.73 & 14.34 \\
\hline
\end{tabular}

The volume of root is variation was found due to genetical different among the varieties. The similar result of genetical variation was observed by Karistsapol et al., (2013) in broccoli.

The higher TSS in early sowing might be due to low temperature with short day length during root growth and development. The result is corroborated with the finding Priyanka et al., (2018) in radish.

The variation in TSS might be due to genetic make-up of varieties, such kind of genetic differences for quality characters in different radish genotypes had also reported by Panwar et al., (2013) and Priyanka et al., (2018) in radish.

Early sowing significantly increased chemical compositions such as reducing, non-reducing and total sugars compared to late date of sowing affected on quality parameter, these findings are in close accordance with the findings of Refay (2010) in sugar beet.

Chemical compositions such as reducing, non-reducing and total sugars are different varieties exhibited differences in quality parameters which might be due to its genetic makeup, same results are close accordance with the findings of Refay (2010) in sugar beet.

\section{Interaction effect of sowing date and} different varieties

Data presented in Table 2 showed significant interaction effect of varying sowing times and different varieties on root yield per plot, root yield per hectare and productivity per day. Significantly maximum root yield per plot $(7.62 \mathrm{~kg})$, root yield per hectare $(24.18 \mathrm{t})$ was recorded in treatment combination of $\mathrm{d}_{2} \mathrm{v}_{2}$ $\left(15^{\text {th }}\right.$ October, Pusa Vasuda) which was statistically at par with $\mathrm{d}_{2} \mathrm{v}_{1}$ and $\mathrm{d}_{1} \mathrm{v}_{2}$. 
Likewise, significantly maximum productivity per day $(308.81 \mathrm{~kg})$ was noted in treatment combination $\mathrm{d}_{2} \mathrm{v}_{2}$ which was statistically at par with $d_{2} v_{1}$. This might be due to the suitability of variety to the particular climatic conditions for its vigorous growth and root development. Decrease in these parameters resulted by delayed in planting is due to shorter growing period and vegetative growth which may not supply more photosynthates from leaves to root. Different variety might be attributed to its genetic makeup and intolerance to low temperature conditions under early sowing conditions, Latha et al., (2012). Similar results were observed by Alam et al., (2010) in radish.

\section{References}

Alam, M.; Farooque, A. M.; Nuruzzaman, M. and Jamal Uddin, A. F. M. (2010). Effect of sowing time on growth and yield of three radish (Raphanus sativus L.) varieties. Bangladesh Research Publication Journal. 3(3): 998-1006.

Dongarawar, L. N.; Kashiwar, S. R.; Ghawade, S. M. and Dongarawar, U. R. (2018) Varietal Performance of Radish (Raphanus sativus L.) Varieties in Black Soils of Vidharbha-Maharashtra, India. International Journal of Current Microbiology and Applied Sciences. 7(1): 491-501.

Ebrahimi, M.; Hassandokht, M. R. and Payvast, G. H. (2013). Effect of sowing dates on some quantitative and qualitative traits of three landraces of black radish (Raphanus sativus var. niger). Adv. Environ. Bio. 7(1): 136140.

Kabir, A.; Ali, A.; Waliullah, M. H.; Rahman. M. M. and Rashid, A. (2013). Effect of spacing and sowing time on growth and yield of carrot (Daucus carota L.). International Journal of Sustainable Agriculture. 5(1): 29-36.
Karistsapol, N.; Quanchit, S. and Sompong, T. (2013). Effect of planting dates and broccoli varieties on their growth and yield responses during rainy season. International Journal of plant, Animal and Environmental Science. 3(2): 121124.

Latha, M.; Reddy, S. S.; Vani, S. and Reddy, R. (2012). Studies on the Effect of Sowing dates on Growth and Root Yield of Certain Carrot (Daucus carota L.) Cultivars. Agriculture: Towards a New Paradigm of Sustainability, Page 116-119.

Mapari, A.V.; Dod, V.N.; Peshattiwar, P. D. and Thorat, A. (2009). Genetic variability in radish. The Asian J. Hort. 4(2), 225-258.

Mirecki, N. (2005). The influence of planting date on growth rate of brussels sprout (Brassica oleracea var. gemmifera) in Agro-Ecological Conditions of the Zeta Plain. Acta Agriculture Serbica, 20(X): 47-57.

Panse, V. G and Sukhatme, P. V. (1985). Statistical methods for Agricultural workers $4^{\text {th }}$ ed., ICAR, New Delhi.

Panwar, N. S.; Mishra, A. C,; Uniyal, S.P.; Pandey, V. and Bali, R.S. (2013) Effect of dates of sowing on yield and quality of radish (Raphanus sativus L.) cultivars under rain fed mid-hill conditions of Uttarakhand. Annuals of Agro- Biotech Research. 18(3): 360363.

Patel, H. T.; Sharma, M. K. and Varma, L. R. (2015). Effect of planting date and spacing on growth, yield and quality of beet root (Beta vulgaris L.) cultivars under north Gujarat climatic condition. Int. J. Agril. Sci. Res.5(4): 119-126.

Priyanka, M.; Swarajya Lakshmi K.; Reddy, S. S. P.; Reddy, D. S. and Bala Krishna, M. (2018). Interaction effect of varieties and sowing dates on growth and quality of radish in Southern agro climatic zone 
of Andhra Pradesh. Int. J. Pure App. Biosci. 6(5): 227-231.

Refay, Y. A. (2010). Root yield and quality traits of three sugar beet (Beta vulgaris L.) varieties in relation to sowing date and stand densities. World Journal Agricultural Science. 6(5):589-594.
Salah, A.; Khalil, M. E.; El-Sayed Gamal, S. and Authman Adel, M. (2005). Effect of sowing date, nitrogen fertilizer and row space on yield and quality of sugar beet crop. Annals of Agriculture Science, Moshtohor. 43(1):11-24.

\section{How to cite this article:}

Ladumor, R. G., B. M. Nandre, M. K. Sharma, V. R. Wankhade and Joshi, P. C. 2020. Performance of Different Varieties of Carrot (Daucus carota L.) with Respect Yield, Quality and Chemical Compositions under Varying Sowing Times. Int.J.Curr.Microbiol.App.Sci. 9(02): 126-132. doi: https://doi.org/10.20546/ijcmas.2020.902.015 